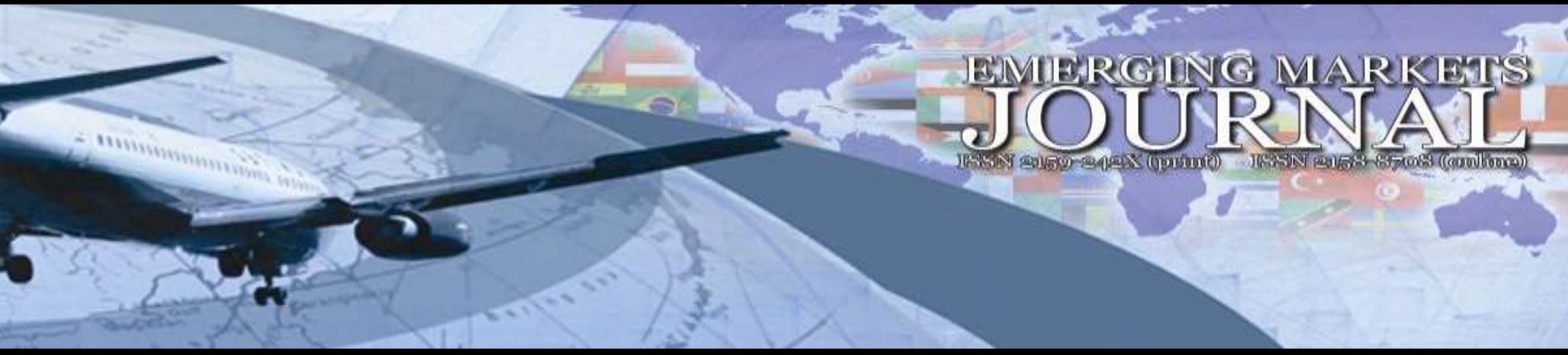

\title{
Organizational Leadership Styles and Employees' Performance in Nigerian Deposit Money Banks
}

\section{Saidi Adedeji Adelekan}

Dominican University, Nigeria $\mid$ adelekan.s@ dui.edu.ng

\section{Patience Erigbe}

Mountain Top University, Nigeria | perigbe@yahoo.com

Volume 10 No 2 (2020) ｜ ISSN 2158-8708 (online) ｜ DOI 10.5195/emaj.2020.202 | http://emaj.pitt.edu

\begin{abstract}
The concept of organizational leadership has engendered a lot of arguments. This is because the effect of leadership on every human endeavor cannot be over emphasized. This study examines the effect of organizational leadership styles, particularly transformational and servant leadership styles on deposit money banks (DMBs) employees' performance in Nigeria. The study employs survey research design, through the administration of structured questionnaire on some selected employees of Guaranty Trust Bank, United Bank for Africa and First Bank. The research instrument was validated through content validity index, while test-retest method was employed in ascertaining the reliability of the research instrument. The findings revealed that transformational leadership and servant leadership styles have positive and significant combined effect on deposit money banks employees' performance $(\mathrm{F}-\mathrm{stat}=58.02 * 0.000)$. The adjusted coefficient of determination (adjusted R2) suggested that, 39.4\% variation in employees' performance is accounted for by transformational leadership and servant leadership styles. The t-value revealed that when the two variables (transformational leadership and servant leadership styles) are combined, they both have positive and significant effect on deposit money banks employees' performance. Therefore, it can be concluded that transformational leadership and servant leadership styles both have individual as well as combined positive and significant effect on deposit money banks employees' performance.
\end{abstract}

Keywords: Organizational Leadership Styles, Transformational Leadership Style, Servant Leadership Style, Employees' Performance, Deposit Money Banks

\section{(cc) EY}

New articles in this journal are licensed under a Creative Commons Attribution 3.0 United States License.

\section{UILIS D-Sente}

This journal is published by the University Library System of the University of Pittsburgh as part

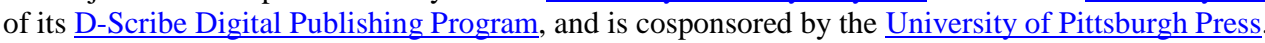




\section{Organizational Leadership Styles and Employees' Performance in Nigerian Deposit Money Banks}

\author{
Saidi Adedeji Adelekan \\ Patience Erigbe
}

\section{Introduction}

The performance of the employees in a highly competitive industry like the banking sector has propelled scholars and practitioners to ascertain the determinants of employees' performance. Some empirical studies have investigated various determinants of employees' performance. Among the various variables examined in extant literature, the leadership style of the top executives has been identified as an important determinant of employees' performance. In people and service oriented enterprises, such as deposit money banks, employees' performance and overall organizational success depends on the leadership style of the managers (Buil, Martínez \& Matute, 2019). This is because the leadership style of the top executives affect employees' behaviors, attitudes and emotions as well as their interaction with customers (Avolio et al., 2004; Buil, Martínez \& Matute, 2019; Wallace et al., 2013).

Prior studies in the organizational leadership domain provide empirical evidence of the existence of positive relationship between some organizational leadership styles and employees' performance as well as firms' competitiveness (Buil, Martínez \& Matute, 2019; Eva, Robin, Sendjaya, van Dierendonck, \& Liden, 2019; Farahnak, Ehrhart, Torres, \& Aarons, 2020; Giambatista, McKeage \& Brees, 2020; Wu, Liden, Liao \& Wayne, 2020; Yavuz, 2020). However, further research is needed regarding the specific organizational leadership styles that impact employees' performance. Furthermore, it also becomes necessary to investigate if a combination of organizational leadership style can be employed towards the enhancement of employees' performance (Buil, Martínez \& Matute, 2019; Yavuz, 2020).

Given the premises above, it is pivotal to examine the link between organizational leadership styles and employees' performance. It is also important to review the essence of transformational and servant leadership styles in the ever-evolving resources constrained environment. The intent of this paper is to ascertain the effect of transformational and servant leadership styles on deposit money banks employees' performance.

In line with the research objective, the following hypotheses were tested:

$\mathrm{H}_{\mathrm{O}} 1$ : Transformational leadership style does not significantly affect deposit money banks employees' performance.
$\mathrm{H}_{\mathrm{O}}$ 2: Servant leadership style does not significantly affect deposit money banks employees' performance.

$\mathrm{H}_{\mathrm{O}}$ 3: Transformational leadership and servant leadership styles do not have significant combined effect on deposit money banks employees' performance.

This study is significant in three-fold: Firstly, it extends previous studies on organizational leadership styles in general and transformational leadership as well as servant leadership styles in particular. This is through the examination of the combined effect of the two independent variables (transformational leadership and servant leadership styles) on the dependent variable (employees' performance). Secondly, the findings and policy implications of this study will be relevant to the banking sector. Finally, the study opens new research vista in transformational leadership and servant leadership styles.

This paper is segmented into five segments: The first segment introduces the subject matter as well as providing the statement of problem and hypotheses. The second segment provides a conceptual and theoretical review of literature of the subject matter. The third segment presents the research methodology adopted for this study. The fourth segment presents the findings and discussion. Finally, the fifth segment provides the conclusion and recommendations.

\section{Literature Review}

The effort to conceptualize and ascertain a better leadership approach has spanned centuries and it is still ongoing. The concept of leadership has evolved over the years. At a certain time, it was attributes and inherent qualities, for another it was behavior and the actions made. Very recently, leadership depends solely on followership, attributes, and abilities (Wu, Liden, Liao \& Wayne, 2020). As a leader, if you had an opportunity to undo any wrong decision made, what would it be? Which challenges can be solved with a particular approach? What is your leadership style's plausibility? The significance of these theories is that, they provide insight into how to effectively lead the dynamism of leadership and how leaders perform.

The adoption of only one leadership style is no longer feasible and current studies seek to understand the attributes and skills required to effectively inspire and lead an organization or society to its stated goals (Hunt \& Fedynich, 2019). Udo-Akang (2012) notes that early leadership theories have been relegated to the past due to the evolution of the concept of leadership. Miska and Mendenhall (2018), on the other hand, are of the opinion that contemporary investigations into the concept of leadership comprise transformational, behavioral, situational and servantship leadership styles, among others. However, the acceptance of a universal concept of leadership remains elusive, since the understanding of the concept of leadership constantly evolves. There is no universally accepted methodology on the description and methodology of leadership characteristics since the concept is based on the belief and situations at a point in time (Middlehurst, 2008). This study provides an insight into the concept of organizational leadership styles. With 
special focus on transformational and servant leadership styles, as it evolves from early times, to the present and the future in an attempt to establish a robust view of the essence of organizational leadership.

Transformational leadership looks at the symbiotic relationship between leaders and the employees, and how they mutually help each other towards achieving predetermined organizational goals through ethical behavior and increase motivation (Miska and Mendenhall, 2018). The burden of leadership is rested upon all the actors in the organization, working towards established goals, within the organization (King, 1990). This form of leadership is based on charisma and charismatic qualities (Ronay \& Vugt, 2014). Transformational leaders create a conducive working environment and adapt to changes and make the employees stay in line with organizational changes without coercion (Farahnak, Ehrhart, Torres, \& Aarons, 2020; Malakyan, 2014).

Servant leadership arises from the modern theories. It emphasizes the leader as a servant to the employees and not the other way-round. It depicts a leader who cares for his/her subordinates (Northouse, 2015). The leader is more concerned with the needs of the employees and prioritizes such needs. Malakyan (2014) suggests that, servant leadership creates the opportunity for the followers to rise to the top. The servant leadership concept in modern era looks at the interchangeability of the leaders and employees' roles based on situational dictates. This concept is progressing towards leadership as a social construct that connects the different aspects of group dynamics, the non-intangible factors and the environment (Middlehurst, 2008).

However, a major criticism of servant leadership in the modern era is that, it seems more suitable for a set of individuals, rather than meeting a specific requirement (Bryman, 2009). More attention should be paid to key situational elements that could determine if servant leadership abilities could be exhibited at all times and if leaders will actually be more effective in the application of this leadership style.

Employees' Performance is about the effective and efficient utilization of all resources. Resources include time, people, knowledge, finance, information, equipment, land, electricity and raw materials. Employees' Performance can be seen from the perspective of employees' productivity, which is the ratio of output to input. It is a measure of how efficiently and effectively an employee uses inputs such as raw materials and capital to produce outputs such as goods and services and how such employee relates with the customers. An enhancement in performance implies that more goods and services are produced with the same amount of raw material and capital. It is not about cutting costs, but "doing things right" and "doing the right things" to achieve maximum efficiency and value. Productivity is the ratio of what is produced to what is required to produce it (Gronroos \& Ojasalo, 2004).

The theory underpinning this study is the contingency theory. The theory postulates that, effective leadership is determined by the followers' or employees' approval or rejection of the leader. In essence a successful leader does not depend solely on attributes and intellect alone, he also depends on the employees' abilities and attributes. The contingency theory of leadership concentrate on unique situational variables that can decide which leadership style is most appropriate for a particular work scenario (Malakyan, 2014). Under this theory, not a single style of leadership is generally acceptable and performance depends on a number of factors, and these include leadership style, characteristics of supporters and situation attributes (Cherry, 2012).

As a result, a contingency factor is any measure required to be taken into account in designing a company or one of its elements in a relevant environment. Contingency Theory asserts that effective leadership relies on the level of understanding existing among employees and leadership and an identified situation warrants it (Lamb, 2013). House and Aditya (1997) posit that, efforts by scholars to establish the very best style of leadership have been inconsistent and insubstantial and this has brought about the contingency theory.

The contingency theory of leadership was a progressive step away from the earlier leadership theories. This is because; there was enough data and studies in management and leadership behavior. However, the contingency theory does not consider the roles and effects of subordinates in the leadership process. The theories also ignored the environment in which the leader exists (Malakyan, 2014). The contingency theory also lacks clarity, and societies and organizations have become more complex and complicated than the theory can assume.

\section{Methodology}

This section presents the methodology adopted to carry out this study. As such, it focused on the methodology employed to ascertain the effect of organizational leadership on employees' performance in Nigerian deposit money banks. This session begins with the research design, and continues to the population for the study, the sample size, research instrument, tests of validity and reliability of instrument, method of data collection, model specification and the method for data analysis.

This study employed the survey research design. This is because data on the subject matter is not readily available and survey research design tends to aid the understanding of the phenomenon under investigation. Scholars with related objectives equally employed survey research design (Buil, Martínez \& Matute, 2019; Farahnak, Ehrhart, Torres, \& Aarons, 2020; Giambatista, McKeage \& Brees, 2020; Wu, Liden, Liao \& Wayne, 2020).

The population of this study comprise of 30.524 employees of three selected deposit money banks, namely: Guaranty Trust Bank, United Bank for Africa and First Bank. The reason for chosen the three deposit money banks is because they are among the top ten deposit money banks quoted on the Nigeria Stock Exchange. The employees of the three selected banks constituted the element of observation of this study. The number of employees of selected banks is stated below: 
Table 1: The Number of Employees of Selected Banks

\begin{tabular}{|l|l|r|}
\hline S/N & Name of Company & $\begin{array}{r}\text { Number of } \\
\text { Employees }\end{array}$ \\
\hline 1 & Guaranty Trust Bank & 10.000 \\
\hline 2 & United Bank for Africa & 12.908 \\
\hline 3 & First Bank & $7, .616$ \\
\hline & TOTAL & 30.524 \\
\hline
\end{tabular}

Source: Authors' compilation

The study employed stratified and simple random sampling technique. The population was divided into three strata based on the three banks and a simple random sampling was carried out in each stratum. The sample size of the study was determined using Raosoft sample size determination method, at $95 \%$ confidence level and 5\% confidence interval, which gave a sample size of 379 . A non-response rate of $20 \%$ was assumed, which increased the sample size to $454(379+75)$. The sample allocated to each selected bank is stated below:

Table 2: The Sample Allocated to Each Selected Bank

\begin{tabular}{|l|l|l|}
\hline S/N & Name of Company & $\begin{array}{l}\text { Number } \\
\text { Employees }\end{array}$ \\
\hline 1 & Guaranty Trust Bank & 151 \\
\hline 2 & United Bank for Africa & 152 \\
\hline 3 & First Bank & 151 \\
\hline & TOTAL & 454 \\
\hline
\end{tabular}

Source: Authors' compilation

The study employed a Likert scale questionnaire, rated as follows: (1) SD: Strongly Disagree, (2) D: Disagree, (3) U: Undecided (4) A: Agree, (5) SA: Strongly Agree. The questionnaire consisted of four sections. Section A obtained demographic information and Section B, C \& D addressed the research objectives. Both construct validity and content validity were met by the instrument. For construct validity, the questionnaires were divided into four sections to ensure that each section assess information for a specific objective, and also ensure that the same was closely tied to the conceptual framework for this study. The content validity of the instrument was tested using content validity index (CVI), by using eight independent assessors, who are academics. Each of the independent assessors rated the questionnaire items on a two-point rating scale of relevant (R) and not relevant (NR). The content validity index was obtained by employing the CVI formula:

$\mathrm{CVI}=\mathrm{n} / \mathrm{N}$

Where;

$\mathrm{N}=$ Total number of items in the instrument, while $\mathrm{n}=$ numbers of items rated as relevant.

The CVI gave a value of 0.901, which according to Ngoma et al, (2017), indicated that the instrument is highly relevant. Therefore, the instrument is valid.
To test the reliability of the instrument (questionnaire), the test-retest method was employed. The instrument was administered on thirty employees Access Bank (A non-participating bank). This was done twice within an interval of fourteen days. Thereafter, the outcomes of the first and second pilot study were correlated and the following values were obtained: 0.8921 (transformational leadership), 0.7384 (servant leadership) and 0.7875 (employees' performance).

\section{Model Specification}

The model aggregates the elements of organizational leadership (transformational and servant leadership). It examined how these elements individually and jointly affect the employees' performance of the selected Deposit Money Banks (Guaranty Trust Bank, United Bank for Africa and First Bank). The model addresses the main objective of the study, which is to examine the effect of organizational leadership on the employees' performance of the selected Deposit Money Banks. The model specification is stated below:

The theory underpinning this study is the contingency theory of leadership.

Model 1

The model specification for hypothesis one is stated below:

$E P=f(T L)$

$\mathrm{EP}=\beta_{0}+\beta_{1} T L i+\mu_{i}-----(i i)$

Where;

EP represents Employees' Performance

TL represents Transformational Leadership

$\beta_{0}$ is the constant term

$\beta_{1}$ is the coefficient of the estimator.

$\beta_{1}>0$

$\mu$ is the error term

Based on the apriori expectation, it is expected that transformational leadership will have a positive impact on deposit money banks employees' performance. Hence, the parameter of transformational leadership should have a positive sign.

\section{Model 2}

The model specification for hypothesis two is stated below:

$E P=f(S L)$

$\mathrm{EP}=\beta_{0}+\beta_{1} S L i+\mu_{i}-----(i i)$

Where:

EP represents Employees' performance

SL represents Servant Leadership

$\beta_{0}$ is the constant term

$\beta_{1}$ is the coefficient of the estimator.

$\beta_{1}>0$

$\mu$ is the error term

Based on the apriori expectation, it is expected that servant leadership will have a positive impact on deposit money banks employees' performance. Hence, 
the parameter of servant leadership should have a positive sign.

Model 3

The model specification for hypothesis three is stated below:

$E P=f(T L, S L)$

$E P=\beta_{0}+\beta_{1} T L_{i}+\beta_{2} S L_{i}+\mu_{i}------(i i)$

Where:

EP represents Employees' Performance

TL represents Transformational Leadership

SL represents Servant Leadership

$\beta_{0}$ is the constant term

$\beta_{1}, \beta_{2}$, are the coefficient of the estimator.

$\beta_{1}, \beta_{2}>0$

$\mu$ is the error term

Based on the apriori expectation, it is expected that transformational leadership and servant leadership will both have a positive impact on employees' performance. Hence, the parameters of transformational leadership and servant leadership should both have a positive sign.

The Ordinary least square (OLS) method of regression analysis was employed to estimate the regression models for all the hypotheses. The OLS was employed in order to examine if the independent variables (transformational leadership and servant leadership) affect the dependent variable (employees' performance). The benchmark for accepting or rejecting the null hypothesis was a level of significance of five percent (0.05). STATA version 14 software was used for the analysis.

\section{Results and Discussions}

454 copies of the structured questionnaires were administered on selected employees of the three deposit money banks. However, only 391 copies were returned and found useable, which represent $86 \%$ response rate. Thus, the analysis was based on the returned 391 copies of the instrument.

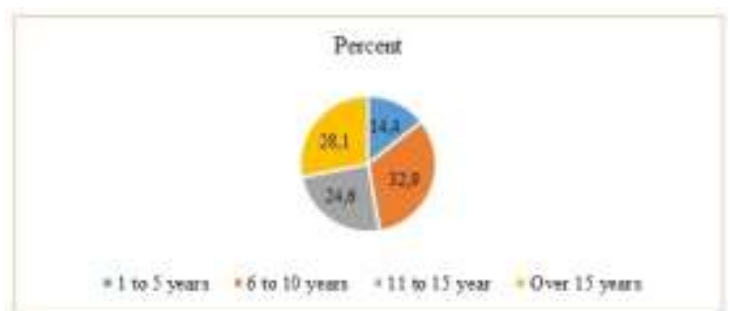

Figure 1. Indicating Respondents Work Experience

$$
\text { Source: Authors' compilation }
$$

Figure 1 revealed that most of the respondents (32.9\%) are working in their bank between 6-10 years, while $28.1 \%$ are working in their bank for over 15 years. Also, $24.6 \%$ of respondents are working in their bank between $11-15$ years, while $14.4 \%$ are working for $1-5$ years. This implies that, most respondents are conversant with their bank's organizational leadership style.

Hypotheses Testing

Hypothesis One (transformational leadership style does not significantly affect deposit money banks employees' performance)

Table 3: Summary of Hypothesis 1 Result (Dependent Variable - Employees' Performance)

\begin{tabular}{lcll}
\hline Variable(s) & Coefficient & $\begin{array}{l}\text { T- } \\
\text { statistics }\end{array}$ & $\begin{array}{l}\text { P- } \\
\text { Value }\end{array}$ \\
\hline C & 11.69531 & 7.99 & 0.0000 \\
Transformational & 0.4216876 & 6.79 & 0.0000 \\
$\begin{array}{l}\text { Leadership } \\
\text { F-Statistics 55.28 (0.0000) }\end{array}$ & R-Square $=0.2101$ \\
\hline
\end{tabular}

Source: Authors' computation from STATA 14

The results on Table 3 above revealed a positive and significant relationship between transformation leadership style and employees performance $($ coefficient $=0.4216876, \mathrm{t}=6.79, \mathrm{p}$-value $=0.000$ ). This indicates that the better the transformational leadership style of the deposit money banks, the higher the level of employees' performance of the banks. The coefficient of determination $\left(\mathrm{R}^{2}\right)$ suggested that $21 \%$ variation in employees' performance is explained by transformational leadership style, while the F-statistics suggest that the model is reliable for decision and policy making.

Hypothesis Two (servant leadership style does not significantly affect deposit money banks employees' performance)

Table 4: Summary of Hypothesis 2 Result (Dependent Variable - Employees' Performance)

\begin{tabular}{lrll}
\hline Variable(s) & Coefficient & $\begin{array}{l}\text { T- } \\
\text { statistics }\end{array}$ & P-Value \\
\hline C & 7.085674 & 5.87 & 0.0000 \\
Servant & 0.629763 & 9.89 & 0.0000 \\
Leadership & & & \\
F-Statistics $=94.92(0.0000)$ & R-Square $=0.3375$ \\
\hline
\end{tabular}

Source: Authors' computation from STATA 14

It is evident from the result above (Table 4) that servant leadership style, positively and significantly affect employees' performance (coefficient $=0.629763$, $\mathrm{t}=9.89, \mathrm{p}$-value $=0.000)$. Therefore, an improvement in the servant leadership style will enhance employees' performance. The coefficient of determination $\left(\mathrm{R}^{2}\right)$ suggested that $33.7 \%$ variation in employees' performance is accounted for by servant leadership style, while the F-statistics suggest that the model is reliable for decision and policy making. 
Hypothesis Three (transformational leadership and servant leadership styles do not have significant combined effect on deposit money banks employees' performance)

Table 5: Summary of Hypothesis 3 Result (Dependent Variable - Employees' Performance)

\begin{tabular}{lcll}
\hline Variable(s) & Coefficient & $\begin{array}{l}\text { T- } \\
\text { statistics }\end{array}$ & $\begin{array}{l}\text { P- } \\
\text { Value }\end{array}$ \\
\hline C & 3.435672 & 6.39 & 0.000 \\
$\begin{array}{l}\text { Transformational } \\
\text { Leadership }\end{array}$ & .1503511 & 3.05 & 0.003 \\
$\begin{array}{l}\text { Servant } \\
\text { Leadership }\end{array}$ & .2608626 & 4.06 & 0.000 \\
$\begin{array}{l}\text { F-Statistics = 58.02 (0.0000) } \\
\text { R-Square }=0.415, \\
\end{array}$ & $\begin{array}{l}\text { Adj-R-Square= } \\
0.394\end{array}$ \\
\hline
\end{tabular}

Source: Authors' computation from STATA 14

The result summary on Table 5 above revealed that transformational leadership and servant leadership styles have positive and significant combined effect on deposit money banks employees' performance (F-stat= $58.02 * 0.000)$. The adjusted coefficient of determination (adjusted $\mathrm{R}^{2}$ ) suggested that, $39.4 \%$ variation in employees' performance is accounted for by transformational leadership and servant leadership styles. The t-value revealed that when the two variables (transformational leadership and servant leadership styles) are combined, they both have positive and significant effect on deposit money banks employees' performance.

\section{Conclusion and Recommendations}

The empirical findings of this study provide evidence that, transformational leadership and servant leadership styles play important roles in deposit money banks employees' performance. Therefore, it can be concluded that transformational leadership and servant leadership styles both have individual and combined positive as well as significant effect on deposit money banks employees' performance.

In line with the findings of this study, the following recommendations are made: Nigerian deposit money banks should employ transformational leadership and servant leadership styles towards the enhancement of their employees' performance. Also, the Central Bank of Nigeria (CBN) should encourage the adoption of transformational leadership and servant leadership styles by banks, so as to enhance their employees' performance, which tends to positively affect their overall performance. Finally, the board of directors of deposit money banks should encourage the formulation of transformational leadership and servant leadership styles policy.

\section{References}

Avolio, B.J., Gardner, W.L., Walumbwa, F.O., Luthans, F., May, D.R., 2004. Unlocking the mask: a look at the process by which authentic leaders impact follower attitudes and behaviors. Leadersh. Q. 15 (6), 801-823.

Buil, I., Martínez, E., \& Matute, J. (2019). Transformational leadership and employee performance: The role of identification, engagement and proactive personality. International Journal of Hospitality Management, 77, 64-75.

Cherry, K. (2012). Leadership theories major leadership theories. Available from: http: //psychology. about.com/od/leadership/p/leadtheories.htm. [A ccessed: 12 December 2019]

Eva, N., Robin, M., Sendjaya, S., van Dierendonck, D., \& Liden, R. C. (2019). Servant leadership: A systematic review and call for future research. The Leadership Quarterly, 30(1), 111-132.

Farahnak, L. R., Ehrhart, M. G., Torres, E. M., \& Aarons, G. A. (2020). The influence of transformational leadership and leader attitudes on subordinate attitudes and implementation success. Journal of Leadership \& Organizational Studies, 27(1), 98-111.

Giambatista, R., McKeage, R., \& Brees, J. (2020). Cultures of Servant Leadership and Their Impact. The Journal of Values-Based Leadership, 13(1), 12.

Grönroos, C., \& Ojasalo, K. (2004). Service productivity: Towards a conceptualization of the transformation of inputs into economic results in services. Journal of Business Research, 57(4), 414-423.

Hunt, A., \& Fedynich, A (2019). Leader, past, present and future: An evolution of an idea'. Journals of Art and Humanities, 8(2), 56-73.

King, A.S. (1990). Evolution of leadership theory. Vikalpa. The Journal of Decision Makers, 15(2), 43-54.

Lamb, R. (2013). How can managers use participative leadership effectively? Retrieved from http://www.task.fm/participative-leadership. [Accessed: 17 March 2019] 
Malakyan, P.G. (2014). Followership in leadership studies. Journal of Leadership Studies, 7(4), 622 .

Miska, C., \& Mendenhall, M.E. (2018). Responsible leadership: A mapping of extant research and future directions'. Journal of Business Ethics, $148(1), 117-134$.

Northouse, P. (2015). Leadership: Theory and Practice. New York: Sage Publication.

Ronay, R., \&Vugt, M.V. (2014). The evolutionary psychology of leadership: Theory, review, and roadmap. Organizational Psychology Review, 4(1), 74-95.

Udo-Akang, D. (2012). Theoretical constructs, concepts, and applications. American International Journal of Contemporary Research, 2(9), 8997.

Wallace, E., de Chernatony, L., Buil, I., 2013. Building bank brands: how leadership behavior influences employee commitment. J. Bus. Res. 66 (2), 165-171.

Wu, J., Liden, R. C., Liao, C., \& Wayne, S. J. (2020). Does manager servant leadership lead to follower serving behaviors? It depends on follower self-interest. Journal of Applied Psychology.

Yavuz, M. (2020). Transformational Leadership and Authentic Leadership as Practical Implications of Positive Organizational Psychology. In Handbook of Research on Positive Organizational Behavior for Improved Workplace Performance (pp.122-139). IGI Global. 